\title{
ARを用いた多国語の史跡案内システム
}

\section{The Historic-relics Guidance System in Multiple Languages with}

\section{Augmented Reality (AR)}

\author{
山島一浩 \\ Kazuhiro YAMASHIMA ${ }^{1 *}$
}

\section{1 筑波学院大学}

Tsukuba Gakuin University

干305-0031 茨城県つくば市吾妻3-1

E-mail: mt-is@tsukuba-g.ac.jp

*連絡先著者 Corresponding Author

近年、スマートフォンの普及に伴い、人がその場の位置情報を活用した新たなデータセットが誕生 している. ARを用いることで、位置情報を活用した新たなデータセットが誕生し、自由な視点でデー タを閲覧する必要性が高まってきている. そこで著者は、A-Frame用いてWebでARを使った案内情 報を、日本語、英語、中国語で表示する. 紹介寸るのは、つくば市にある奈良・平安時代におかれた 郡役所の跡「平沢官衙遺跡」である.

In recent years, as use of the smart phone becomes widespread, new data sets for which people utilize their location information are developed. As AR creates the new data sets utilizing location information, the necessity of looking at data from a unfettered viewpoint is increasing. So, using A-Frame, the author displays the guidance information with AR on the Web in Japanese, English, and Chinese. "Hirasawakanga-iseki Ruin," the district office placed from the Nara era to Heian era located in Tsukuba City will be introduced.

キーワード: AR, A-Frame, GPS, Google Map, Smartphones

Keywords: AR, A-Frame, GPS, Google Map, Smartphones 


\section{1 はじめに}

近年、スマートフォンの普及に伴い、人がそ の場の位置情報を活用した新たなデータセッ トが誕生している. 例えばスマートフォンの GPSを使って、カメラを使って写真情報を集め る等である。この位置情報を活用し、自由な視 点でデータを閲覧するなど、今後は、ARを用 いてコンテンツを構成する必要性が高まって きている.

そこで著者は、史跡情報をWebでARを用い た案内情報を、日本語、英語、中国語で表示 するシステムを構築した. 案内で紹介するの は、つくば市にある奈良・平安時代におかれ た郡役所の跡「平沢官衙遺跡」である.

\section{WebページのAR}

\section{1 レスポンシブWebデザイン}

レスポンシブWebデザインでは、端末の画 面のサイズや向きに適応するページを作成す ることができる。Webページを最適化して、拡 大縮小によってコンテンツがあらゆる端末の ブラウザに収まるようにするからである。

現在、Webサイトをつくる際には、PC画面で、 960px、スマートフォン画面で750pxのデザイン が用いられている。

このような、画面の変化に、レスポンシブ Webデザインは、得意であり、Html5やCSS3の 登場で、Webページの書き方は、一層強化さ れている。

\subsection{A-FrameでAR}

ARは，現実空間上にCGなどの仮想現実を 表示して実現する.

A-Frameは、HTMLのタグを記述するだけ でWebVRが実装できるフレームワークであ る.A-Frameを使うだけで3Dの描画はもち ろんの事, ドラッグ操作や傾き検出などを 行う機能が組み込まれている。
ARツールとして，2017年に，AR. jsが開 発された. AR. jsの特徵は，まず，オープ ンソースなので，無料である. スマートフ オンでもオープンソースのARツールの AR. jsで，様々なプラットフォーム上でイ ンストールすることなく, 動かすことがで きる.

\section{WebページのGPS}

\section{1 空間位置推定}

まず、現実空間をどのようにとらえるか. SLAMのような空間位置推定と環境地図作 成には、課題が多く残されている.

空間位置推計は、撮影しているカメラの 位置がその空間内でどこにいるか把握す ることであり、環境地図作成は、位置の推 定やマップ作成には測域センサ、カメラ、 エンコーダなどが利用されることが多い.

\subsection{GPS}

GPSは、地球上空の衛星と通信し、測位を 行っているが、情報の取得に時間がかかっ たり、電波の届きにくい屋内に弱かったり といった弱点がある，スマホやタブレット などの端末では、GPS情報に加え、携帯電 話基地局までの距離を測定することで位 置を推定するA-GPS（Assisted Global Positioning System) を併用している.

A-GPSではこれをIPネットワークで補い、 おおよその位置から判断して測位可能な 衛星の軌道データを送ることで短時間化 を実現している。

\section{Webページのシステム}

\subsection{GASを使う}

GAS(Google Apps Script)は、JavaScriptを ベースにしたプログラミング言語である。

Googleのスプレットシートをデータベースと 
して用い、多言語の利用といらことをGoogle Languageを用いるので、GASを使ってシステ ムに組み込んだ。

\subsection{Google API}

地図を用いること、そして、多言語として自 動翻訳を使おうため、Google APIの利用を考 慮した。

\subsubsection{Geolocation API}

位置情報では、Geolocation APIを用い て、JavaScriptでユーザーの位置情報を扱 う. Geolocation APIには、次のメソッド が用意されている，位置情報の取得、位置 情報取得の詳細オプション、位置情報の取 得項目である。

getCurrentPosition()で、ユーザーの現 在の位置情報を一回だけ取得する.また、 位置情報取得の詳細オプションでは、より 精度の高い位置情報を取得する。

\subsection{Google APIの導入}

多言語の利用の導入として、Google TRANSLATEを用いて、テキストをある言語 から別の言語に翻訳する。言語は、2 文字の 言語コードで指定する。

\section{3 開発}

\section{1 対象地 (平沢官衙遺跡歴史ひろば)}

平沢官衙遺跡は、奈良から平安時代に、 常陸国筑波郡の郡役所跡の遺跡で、国の 史跡指定を受けている．校倉、土倉、板 倉の 3 棟の高床倉庫を復元している.

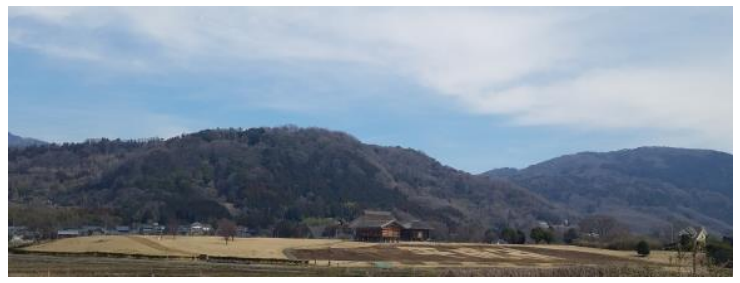

図1 平沢官衙遺跡歴史ひろば

\section{2 データベースの登録}

データベースの登録は, Googleスプレッ トシートを用いた（表1）。L-Lは、経緯度 を登録する。場所のタイトルをTitleが、 日本語は、JANの所に収録する。スプレッ トシートに、データを入力した。

表1 テーブル

\begin{tabular}{|l|l|l|l|l|}
\hline NO & L-L & Title & JAN & URL \\
\hline
\end{tabular}

それから、ツールで、スクリプトエディ タを選択し、GASのdoDoc関数を作成する。 doDoc関数は、記述は単純で、多言語を ContentService. createText0utput() で文 字列を出力する。このデータを API で返 す。

\subsection{Google Mapの表示}

Google Mapに表示をする。地図が現状だ と白くなってしまうので、図2のような画 像をのせた。

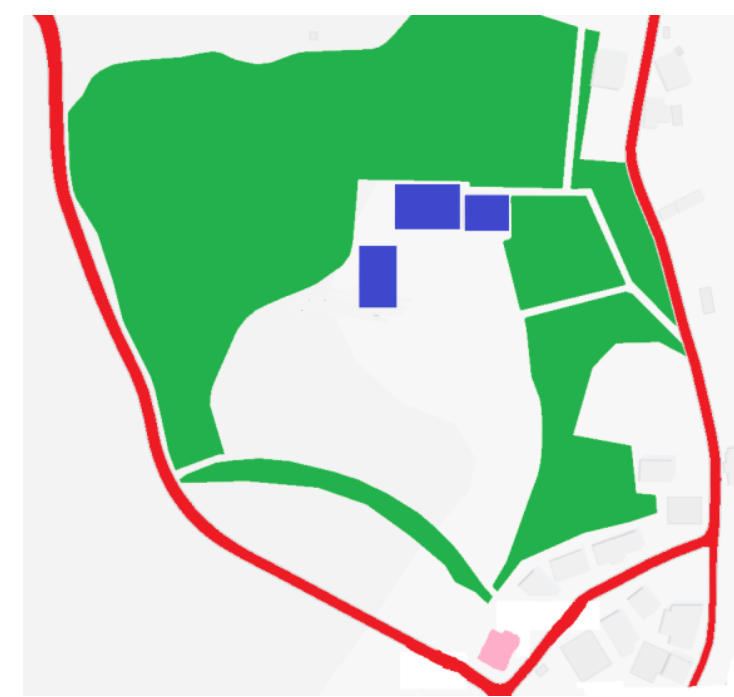

\section{図2 地図と合わせた図の挿入}

あとは、表示位置に印を出す。表示する 印をクリックしたら、ARのWebページが出 力される。

\subsection{ARの出力}

ARを記述したWebページは、GASによって 得られた多言語のテキストを出力する。テ キストは、JavaScriptで、約 $10 \mathrm{~m}$ 範囲で 
表示を行う。A-Frame側でa-textタグで表 示する。

\section{4 結果}

ARの部分は、表示できた.

しかし、翻訳は、十分とは言えず、表2 の追加をした。

\section{表2 テーブル}

\begin{tabular}{|l|l|l|l|l|l|}
\hline NO & L-L & Title & JAN & CHN & EN \\
\hline
\end{tabular}

これは、日本の専門用語に、翻訳が不足

していることが考えられる。

平沢官衙遺跡は、奈良から平安時代に、常陸国 筑波郡の郡役所跡の遺跡で、国の史跡指定を受 けている。校倉、土倉、板倉の3棟の高床倉庫 を復元しています。

例えば、これを本学の留学生に直しても らうと、以下のようになる。

平泽官衙遗址是从奈良到平安时代, 作为常陆国 筑波郡的郡治所遗址, 被指定为国家的历史遗 迹。现正在复原校仓、土仓、板仓三栋高床仓库。

\section{5 考察}

新たな技術を用いて、AR のWebページを 示しているが、確実にAPIの通りにできて いない場合が実在する。

A-Frame用いてWebでARを使った案内情 報を、日本語、英語、中国語で表示するた めに、Google APIを使って変換したのだか、 これは、未だ先のような問題がある.

中国語といっても、中華人民共和国と中 華民国では、異なる。それに対応すること が重要かと思われるが、肝心なことは、そ の国に合わせて理解することが重要と思 われる。

\section{6 まとめ}

ARを用いた多国語の史跡案内システムを 構築した. 作成にあたり、日本の歴史につ いて、多くを考えさせられた。

\section{参考文献}

[1] Ethan Marcotte : Responsive Web Design, http://alistapart.com/article/respon sive-web-design/（2019年4月12 日参照）

[2] Diego Marcos, Don McCurdy, Kevin Ngo, F-Frame,https://aframe.io(2019年4月 1日参照).

[3] Hybrid system, http://www.edepot.com/iphone.html\#iPhon e_A-GPS(2019年4月 15 日参照)

[4] Google App Script, https://www.google.com/script/start/(2019月4 月 1 日参照) 